\title{
Off-Campus Living Among Ekiti State University Students in Southwestern Nigeria: Health and Policy Implications
}

\author{
Fasoro Olatunji Jimoh ${ }^{1}$, Aduayi Victor Adovi ${ }^{2, ~ *, ~ O d u ~ O l u s o l a ~ O l u g b e n g a ~}{ }^{2}$, \\ Bolarinwa Oladimeji Akeem ${ }^{3}$, Amu Eyitope Oluseyi \\ ${ }^{1}$ Pharmacy Department, College of Health Technology, Ijero Ekiti, Nigeria \\ ${ }^{2}$ Department of Community Medicine, Faculty of Clinical Sciences, College of Medicine, Ekiti State University, Ado-Ekiti, Nigeria \\ ${ }^{3}$ Department of Epidemiology and Community Health, Faculty of Health Sciences, College of Medicine, University of Ilorin, Ilorin, Nigeria
}

Email address:

victoraduayi@yahoo.com (A. V. Adovi)

${ }^{*}$ Corresponding author

\section{To cite this article:}

Fasoro Olatunji Jimoh, Aduayi Victor Adovi, Odu Olusola Olugbenga, Bolarinwa Oladimeji Akeem, Amu Eyitope Oluseyi. Off-Campus Living Among Ekiti State University Students in Southwestern Nigeria: Health and Policy Implications. Journal of Health and Environmental Research. Vol. 4, No. 2, 2018, pp. 77-83. doi: 10.11648/j.jher.20180402.15

Received: April 1, 2017; Accepted: December 7, 2017; Published: July 6, 2018

\begin{abstract}
The quest for attaining higher educational levels has increased over the year leading to the dwindling in the availability of hostel accommodation. A cross-sectional descriptive study design was conducted among 312 respondents selected utilizing a multistage sampling technique. Quantitative data was collected using a semi structured self-administered questionnaire. Analysis was done as appropriate on the univarate and bivariate levels using SPSS software version 20 package. An assessment of bed space ownership showed a majority, 198 (63.5\%) did not have bed space with only $114(36.5 \%)$ being the legal occupant of which $51(16.3 \%)$ were with squatters while the remaining $63(20.2 \%)$ were without squatters. Overall, female students made up the greater proportion of students without legal occupancy. Illegal owners of hostel bedspaces (32.8\%) were found to experience more incidences of domestic accidents such as falls, wounds, electric shock, burns and scalds in the hostel compare to legal owners (20.2 Malaria was the predominant ailment experienced by the respondents 95 $(49.2 \%)$, with asthma being the least $6(3.1 \%)$. A greater proportion of the students are not legal occupants of their rooms. They are either squatters, floaters, colonizers or bought the spaces from the rightful owners. It is thereby advocated that universities need to engage in public private partnership using the "Build, Operate and Transfer" (BOT) model to build more hostels within the University premises.
\end{abstract}

Keywords: Off Campus, University Students, Health, Policy Implication

\section{Introduction}

The quest for attaining higher educational levels has increased over the year in Nigeria with more people striving to acquire additional degrees in other to compete favorably in the job market. This has lead to the dwindling in availability of hostel accommodations with most students in tertiary institutions finding it difficult acquiring adequate accommodation. [1] Hence, they are usually left with the option of having to share rooms with many people resulting in over-crowded hostels. Provision of hostel accommodation should be considered as a fundamental responsibility of the institutions, as is one of the several parameters to ensuring state of complete physical and social well-being of the students. The structure, location, facilities and services available are essential for optimum performance of the students. [2] Poor hostel conditions and usage caused by overcrowding may increase vulnerability to injury, disease and even death. [3] Adequate and appropriate housing conditions, on the other hand, not only protects students against health hazards, but also help to promote robust physical, mental and psychological comfort and social vigor.

The prospect for desired healthy accommodation for students is most fundamentally affected by overcrowding. 
Sadly, most existing hostel accommodations are inadequate to foster optimum health or even to protect people against health hazards. In fact, national working group on tertiary education are other research teams have concluded that most Nigerian graduates from public university are increasingly not marketable and not readily employable. [4, 5] Research has shown that $80 \%$ of Nigerian graduates are unemployable. [6] This has been partly attributed to less than optimal academic environment where insufficient classrooms, hostel accommodation, laboratories and other teaching aids make the process of imparting knowledge grossly inadequate. [7] This development has evolved into major public argument, causing the ministry of education and other key stakeholders, and policy analysts to rethink and review existing guidelines aimed at changing this trend. [8] Top in their recommendations are the exploration of strategies aimed at provision of adequate housing for university students. [9].

Studies has shown the independent effect of overcrowding on physical health because the links are confounded by other factors such as generally poor living condition. As a result, this survey was conducted to determine the prevalence of adverse health conditions in On-campus student housing in a tertiary academic institution in south-western Nigeria.

\section{Methods}

A cross-sectional descriptive study design was conducted among a population of 312 students utilizing the Fisher formula for sample size determination. Respondents were selected using the multistage sampling technique. The first step was the selection of the six blocks out of the nine existing blocks using simple random sampling by balloting. The selected six blocks consist of the two blocks of Ajasin hostel of sixty occupants per block, one block of Government Hostel of capacity two hundred occupants and three blocks of Osekita Hostel with a capacity of one hundred occupants per block. The total number of students in the six selected blocks was six hundred and twenty. The second step was the proportional allocation of the sample size across the six selected blocks within the three existing hostels thus,

$$
\begin{gathered}
\left(\frac{\text { Number of students in each block }}{\text { Total number of students in the six selected blocks }}\right) \\
\times \text { Sample size }
\end{gathered}
$$

At Ajasin hostel; The two existing blocks were randomly picked.

$$
\begin{gathered}
\text { Block } A=(60 / 620) \times 350=34 \\
\text { BLOCK B }=(60 / 620) \times 350=34
\end{gathered}
$$

At Government hostel which is a one-block hostel with a capacity of 200 occupants 113 students were selected; $(200 / 620) \times 350=113$.

At Osekita hostel; Blocks 1, 2 and 5 of the six existing blocks were also randomly selected and the respondents were also estimated as follow;

$$
\text { Block } 1,2 \& 3=(100 / 620) \times 350=56.45 \times 3=169
$$

\section{SECOND STAGE}

The second stage involved the use of systematic random sampling in each of the block thus;

$$
\begin{gathered}
\left(\frac{\text { Total number of students in each block }}{\text { Proportion allocated to each block }}\right) \\
=\text { The sampling interval }
\end{gathered}
$$

At Ajasin Block A and B Sampling interval $=(60 / 34)=$ $1.8 \approx 2$ Thus, 2 was used as sampling interval for Block $\mathrm{A} \& \mathrm{~B}$

At Government Hostel Sampling interval $=(200 / 113)=$ $1.8 \approx 2$

At Osekita Hostel sampling interval $=(100 / 56.45)=$ $1.8 \approx 2$

The second step was the selection of the respondents in each block using simple random sampling by balloting. This was achieved by picking yes or no in each of the respondents room.

Quantitative data was collected using a semi structured selfadministered questionnaire. The questionnaire had four sections capturing the social-demographic characteristics of the respondents, residential status and living conditions of respondents, students' awareness of overcrowding and the environmental as well as infrastructural facilities of the respondents' hostel. Verbal consent was obtained from the respondents after detailed explanation of the objectives, scope and benefits of the study had been made known to them Analysis was done using SPSS software version 20 package. Frequency distribution table(s), simple percentages and means were used to present the data. Cross tabulation of important variables was also done. The indices of measurement included the proportion of students whose sickness were associated or aggravated by overcrowding. Chi-square test was used to determine statistical significance of differences in variables observed and $\mathrm{p}$-value was set at $\mathrm{p} \leq 0.05$.

\section{Results}

A majority of respondents, were between the age 21-25 years $(42.6 \%)$ with the fewest number being those that were 30 years and above $(5.4 \%)$. Mean age of the respondents and standard deviation (SD) was $22( \pm 4.2)$. About $68 \%$ of respondents were female compared to their male colleagues $(32 \%)$. Out of the total 312 respondents, $73.4 \%$ were Christians, $25.0 \%$ were Muslims, while other religions accounted for $1.6 \%$ of respondents. A total of $250(80.1 \%)$ were single while the remaining $62(19.9 \%)$ were married. (Table 1) 
Table 1. Socio-Demographic Characteristics of the Respondents (N=312).

\begin{tabular}{lll}
\hline Variable & Frequency & Percentage (\%) \\
\hline Age groups(in years) & & \\
20 and below & 130 & 41.7 \\
$21-25$ & 133 & 42.6 \\
$26-30$ & 32 & 10.3 \\
Above 30 & 17 & 5.4 \\
Mean & $22 \pm 4.2$ & \\
Gender & & \\
Male & 101 & 32.4 \\
Female & 211 & 67.6 \\
Religion & & \\
Christianity & 229 & 73.4 \\
Islam & 78 & 25.0 \\
Others & 5 & 1.6 \\
Marital status & & \\
Single & 250 & 80.1 \\
Married & 62 & 19.9 \\
Physically Challenged & & \\
Yes & 49 & 15.7 \\
No & 263 & 84.3 \\
\hline
\end{tabular}

An assessment of bed space ownership showed a majority, $198(63.5 \%)$ did not have bed space with only $114(36.5 \%)$ being the legal occupant of which 51 (34.9\%) were with squatters while the remaining $63(20.2 \%)$ were without squatters. Majority of the respondents 271 (86.9\%) shared bed while the remaining $41(13.1 \%)$ did not share bed. Overall, female students made up the greater proportion of students without legal occupancy. (Table 2). Furthermore, $251(80.4 \%)$ of the respondents confirmed that there were religious activities in the hostel of which a majority 145 $(57.8 \%)$ admitted that this religious activities had a positive effect on them. It was also observed that effects of religious activities on the respondents had a significant association with students gender $(\mathrm{p}=0.0001)$. Most respondents 194 $(62.2 \%)$ used hostel toilet facilities while the majority 202 $(64.7 \%)$ used water from borehole for domestic activities. (Table 2) However, social conflict often occurred such as common room fight which accounted for about $49 \%$ of conflicts. It was observed that more male students $(16.7 \%)$ allow unauthorized visitor in room at will compared to their female counterparts (14.6\%). However, no significant association was found between practice of allowing unauthorized visitors into rooms and respondents gender.

Table 2. Gender based distribution of hostel their occupants by ownership status and some social behavioural characteristics.

\begin{tabular}{|c|c|c|c|c|}
\hline \multirow{2}{*}{ Variable } & \multicolumn{2}{|l|}{ Gender } & \multirow{2}{*}{ Total $n=$ Frequency $(100.00 \%)$} & \multirow{2}{*}{ Statistical test } \\
\hline & Male n (\%) & Female n (\%) & & \\
\hline Space Ownership Status of the Respondents & & & & $X^{2}=0.59$ \\
\hline Yes & $39(38.6)$ & $75(35.5)$ & $114(36.5)$ & $\mathrm{df}=1$ \\
\hline No & $62(61.4)$ & $136(64.5)$ & $198(63.5)$ & $P=0.617$ \\
\hline Accommodation Resident Status of the Respondents & & & & $X^{2}=2.02$ \\
\hline Legal occupant with squatters & $18(43.9)$ & $33(31.4)$ & $51(34.9)$ & $\mathrm{df}=1$ \\
\hline Legal occupant without squatters & $23(56.1)$ & $72(68.6)$ & $95(65.1)$ & $\mathrm{P}=0.155$ \\
\hline Allow unauthorized Visitor in Room at will & & & & $X^{2}=0.22$ \\
\hline Yes & $19(16.7)$ & $29(14.6)$ & $48(15.4)$ & $\mathrm{df}=1$ \\
\hline No & $95(83.3)$ & $169(85.4)$ & $264(84.6)$ & $\mathrm{P}=0.359$ \\
\hline Responses based on beddings & & & & $X^{2}=0.893$ \\
\hline Those who share bed & $65(64.4)$ & $124(58.8)$ & $189(60.6)$ & $\mathrm{df}=1$ \\
\hline Those who do not share bed & $36(35.6)$ & $87(41.2)$ & $123(39.4)$ & $\mathrm{P}=0.206$ \\
\hline Effects of religious activities on the respondents & & & & $X^{2}=17.36$ \\
\hline Positive & $75(82.4)$ & $101(57.4)$ & $176(65.9)$ & $\mathrm{df}=2$ \\
\hline Negative & $6(6.6)$ & $19(10.8)$ & $25(9.4)$ & $\begin{array}{l}\mathrm{dI}=2 \\
\mathrm{P}=00001 * *\end{array}$ \\
\hline I cannot say & $10(11.0)$ & $5(31.8)$ & $66(24.7)$ & $P=0.0001$ \\
\hline Usage of hostel toilet facilities & & & & $X^{2}=2.05$ \\
\hline Yes & $69(60.5)$ & $125(63.1)$ & $194(62.2)$ & $\mathrm{df}=1$ \\
\hline No & $45(39.5)$ & $73(36.9)$ & $118(37.8)$ & $\mathrm{P}=0.359$ \\
\hline
\end{tabular}

$\chi^{2}=$ Pearson Chi-square, $\mathrm{df}=$ Degree of freedom, *Statistically significant at $\mathrm{p}$ value $<0.05, * *$ Statistically significant at $\mathrm{p}$ value $<0.001$

Illegal owners of hostel bed spaces $(32.8 \%)$ were found to experience more incidences of domestic accidents in the hostel compare to legal owners (20.2\%). A significant association was found between ownership of bed space and risk of experiencing domestic accidents in the hostel ( $p=$ 0.017). Higher rates of Hospital admission were found among Illegal owners (13.6\%) compare to legal owners (11.4\%). (Table 3) However, no significant association was found between Hospital admission and ownership status. Half of the respondents $157(50.3 \%)$ claimed there were places for luggage in the hostel, most of whom kept their luggage in space allocatedA good number respondents $(57.1 \%)$ admitted that the period of stay in the hostels affected their sleep quality, pattern and duration. Malaria was the predominant ailment experienced by the respondents 95 $(49.2 \%)$, with asthma being the least $6(3.1 \%)$. (Fig. 1) Of 178 respondents who experienced ailments in the last 3 months in the hostel, only $23(12.9 \%)$ were admitted to the school clinic. Respondents however, believed that 99(31.1\%) of their room mates were admitted in the last 3 months. Additionally, 88 (28.2\%) respondents claimed that they had accidents in the hostel in the past while $84(26.9, \%)$ agreed that their roommates had accidents. Majority of the respondents $97(42.9 \%$ ) strongly believed that mosquito bites were mainly responsible for their ailments. 


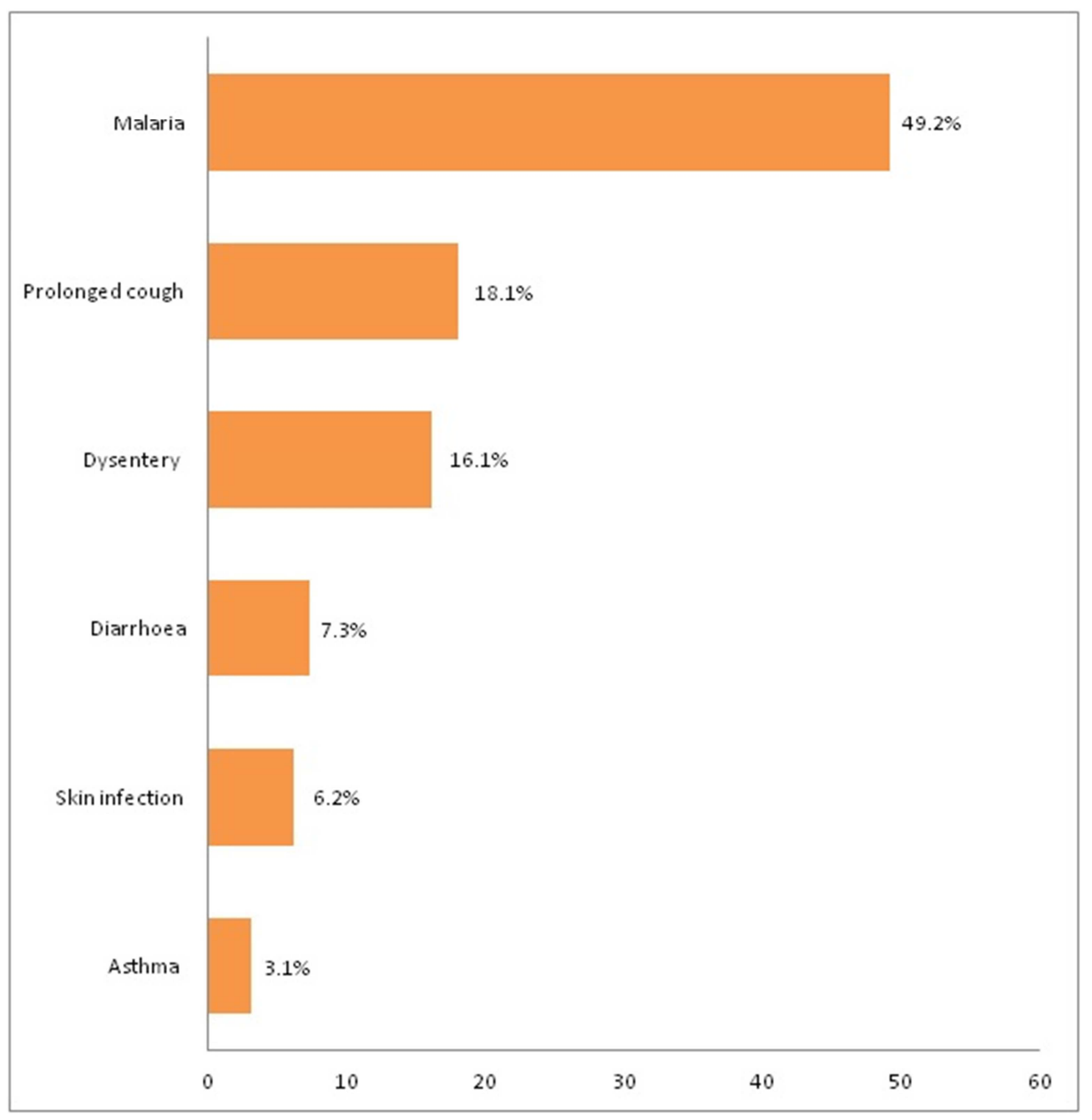

Figure 1. Prevalence of health conditions experienced by respondents in the last 3 months in the hostel.

Table 3. Students Legal ownership of hostel bed space by respondent's experience of adverse health related events, symtoms and some social behavioural characteristics.

\begin{tabular}{|c|c|c|c|c|}
\hline \multirow{2}{*}{ Variable } & \multicolumn{2}{|c|}{ Ownership of Bed space } & \multirow{2}{*}{ Total n (100.00\%) } & \multirow{2}{*}{ Statistical test } \\
\hline & Legal Ownern (\%) & Illegal Ownern (\%) & & \\
\hline Experienced domestic accidents in the hostel & & & & $\mathrm{X}^{2}=5.80$ \\
\hline Yes & $23(20.2)$ & $65(32.8)$ & $88(28.2)$ & $\mathrm{df}=1$ \\
\hline No & $91(79.8)$ & $133(67.2)$ & $224(71.8)$ & $\mathrm{p}=0.017$ \\
\hline $\begin{array}{l}\text { Admission of the roommates of the respondents to the } \\
\text { school clinic in the last } 3 \text { months. }\end{array}$ & & & & $X^{2}=0.32$ \\
\hline Yes & $3(11.4)$ & $27(13.6)$ & $30(12.8)$ & $\begin{array}{l}\mathrm{df}=1 \\
\mathrm{P}=0.570\end{array}$ \\
\hline No & $101(88.6)$ & $171(86.4)$ & $271(87.2)$ & $P=0.5 / 0$ \\
\hline $\begin{array}{l}\text { How the period of stay in the hostel affect sleeping pattern } \\
\text { (multiple response) } n=252\end{array}$ & & & & $X^{2}=7.87$ \\
\hline Quality & $18(36.0)$ & $38(26.0)$ & $56(28.6)$ & $\mathrm{df}=2$ \\
\hline Quantity & $17(34.0)$ & $31(21.2)$ & $48(24.5)$ & $P=0.019$ \\
\hline Both & $15(30.0)$ & $77(52.8)$ & $90(46.9)$ & \\
\hline Engages in regular environmental sanitation activities & & & & $X^{2}=0.28$ \\
\hline Yes & $88(81.5)$ & $161(83.8)$ & $249(83.0)$ & $\mathrm{df}=1$ \\
\hline No & $20(18.5)$ & $31(16.2)$ & $51(17.0)$ & $\mathrm{P}=0.599$ \\
\hline Physically Challenged & & & & $\mathrm{X}^{2}=3.88$ \\
\hline Yes & $24(21.1)$ & $25(12.6)$ & $49(15.7)$ & $\mathrm{df}=1$ \\
\hline No & $90(78.9)$ & $173(87.4)$ & $263(84.3)$ & $\mathrm{P}=0.049$ \\
\hline Presence of separate place for luggage in the hostel room & & & & $X^{2}=2.43$ \\
\hline Yes & $64(56.1)$ & $93(47.0)$ & $157(56.3)$ & $\mathrm{df}=1$ \\
\hline No & $50(43.9)$ & $105(53.0)$ & $155(49.7)$ & $\mathrm{P}=0.119$ \\
\hline
\end{tabular}




\begin{tabular}{|c|c|c|c|c|}
\hline \multirow{2}{*}{ Variable } & \multicolumn{2}{|c|}{ Ownership of Bed space } & \multirow{2}{*}{ Total n (100.00\%) } & \multirow{2}{*}{ Statistical test } \\
\hline & Legal Ownern (\%) & Illegal Ownern (\%) & & \\
\hline Places of luggage placement & & & & \multirow{4}{*}{$\begin{array}{l}X^{2}=8.80 \\
d f=1 \\
P=0.003\end{array}$} \\
\hline Under the bed & & & & \\
\hline Any available space & $28(54.9)$ & $37(30.8)$ & $65(38.0)$ & \\
\hline Luggage space allocated & $23(41.1)$ & $83(69.2)$ & $106(62.0)$ & \\
\hline Main source of water for domestic use & & & & \multirow{4}{*}{$\begin{array}{l}X^{2}=2.05 \\
d f=2 \\
P=0.359\end{array}$} \\
\hline Borehole & $79(69.3)$ & $123(65.4)$ & $202(66.9)$ & \\
\hline Tap & $31(27.2)$ & $62(32.9)$ & $93(30.8)$ & \\
\hline Well & $4(3.5)$ & $3(1.6)$ & $7(2.3)$ & \\
\hline
\end{tabular}

$\chi^{2}=$ Pearson Chi-square, $\mathrm{df}=$ Degree of freedom, *Statistically significant at $\mathrm{p}$ value $<0.05, * *$ Statistically significant at $\mathrm{p}$ value $<0.001$

\section{Discussion}

The student housing has been a major area of concern with increasing number of young people striving to acquire a desired carrier through education in the higher institutions of learning. This increase in population has led to several challenging conditions of student housing such as inadequate infrastructure facilities and overcrowding. From this work it is shown that only about two out of evey three students were without hostel accommodation and likely to be colonizer, co owners, floaters or squatters being common clichés used among students who occupied their spaces illegally. This is finding was corroborated by Yusuf et al were he assessed students access to housing in University of Lagos. [10] However on the contrary, a study by Aluko et al showed a hostel space ownership of more than two-third of the respondents been legal occupiers of a bed space. [11] The difference might be due to the level of orientation, compliance and enforcement of the rules that guide the use of hostels in the two Universities or probably because of poor availability of hostels at the Ekiti State University. The large proportion of squatters among the respondents could be attributed to limited spaces in the hostel. The high transportation cost from the host community might also compel some of the respondents to squat with their colleagues. The consequences of this might led to overutilization of already inadequate facilities like toilet and water, overcrowding and lack of privacy among the students.

Overcrowding in university hostels impacts negatively on the health and well being of students thereby culminating in their poor academic performance. Domestic accidents tend to occur when individuals live in closely neath circumstances as found in overcrowding. [12] The study found that three in ten students who were illegal occupants of spaces experienced varying forms of accidents such as falls, wounds, electric shock, burns and scalds. These findings are similar to the works of Anokye et al who studied students accommodation in Kwame Nkrumah University of Science and technology Ghana. [13] He found, fire outbreaks and falling from heights in addition to and other forms of social accidents such as incidences of theft, robbery and rape. The need to ensure safety in students' hostels will require continued advocacy to hostel managers, school authorities and other stakeholders to perform their expected roles. Likewise, capacity building and students enlightenment programs will maintain a healthy and safe environment which would reduce potential risk of injury and accidents occurring. As regards fire outbreaks, it was observed that a larger proportion of the students in the hostels cooked in the room. Majority of them used cooking stove. Deduction from this analysis was that cooking in the room may also lead to in-door air pollution with its dexterous health effect on the students living in the hostel taking the consideration of duration of stay of the polluted air in the room. It is essential for student housing to provide the basic infrastructure facility needed by the student. Such facilities include, toilets, running water, electricity and a recreation area provision of these facilities in good working order is something that is not always readily available. The study also showed that less than half of the respondents did not use toilet facilities. This is also in contrast with the study carried out in the University of Lagos in which majority of the respondents used the toilet facilities. The reason for the difference might be as a result of the fact that University of Lagos is one of the first generation Universities and is being managed by the Federal Government while the Ekiti State University is being managed by the state Government where funding may not be readily available for proper maintenance as in the case of Federal Universities. This implies that the large proportion of respondents that did not use the toilet might result to open defecation which could also aggravate the spread of communicable diseases like cholera through contamination of underground water or surface water. This corroborates the two separate studies conducted by Boro on Physical Environment and Hygiene status at food service establishments in a tertiary care medical college campus and Aluko assessing the housing situation among students in Lagos. [11, 14]

Absence of appropriate spaces for keeping luggage was widely reported by close to half of respondents. This will further make the room less conducive for occupancy thereby further compounding the already congested rooms.

The results also showed that most of the respondents specified the presence of religious activities in the hostel from which a little above half of the respondents believed that the presence had a positive effect while few opined that the presence had a negative effect on them. This is in agreement with a study by Uchenna in Nigeria which looked at undergraduate religious affiliation and interpersonal relationships in a university setting. [15] This is also in agreement with Bronzaft A. L on the effect of a noise abatement programme on reading ability. [16] The study also 
observed that illegal occupant's allowed unauthorized visitors in their room. This commonly leads social conflicts by increasing risk of fights, thefts and even rape due to infringement of students privacy. The results further corroborate the one carried out in West Bank and Gaza. [17]

The result also showed that majority of the respondents that had experienced one type of ailments during the period of staying in the hostel got knowledge about the possible cause of their ill health. The respondents believed that mosquito bites, poor hygiene, congestion, ventilation problem, cooking in the room and dust were the possible factors that might be responsible for their ill health. The results also showed that more than half of the respondents experienced one type of ill- health or the other during the period of staying in the hostel. The ailments mostly experienced during the period of stay in the hostels include malarial, prolonged cough and diarrhea diseases. Others are, skin infections and asthma. The result is in conformity with the one carried out in West Bank and Gaza in which various diseases range from asthma, cholera, malaria were believed to be caused by overcrowding. [18, 19] This is also in conformity with Dunn J. on housing and inequalities of health among the Vancouver residents. [20]

The Ekiti State University been a citadel of higher learning and functioning amidst economic recession, clearly has a fundamental role of providing adequate and improved housing for students. It is thereby advocated that universities need to engage in public private partnership to build more hostels within the University premises. Popularly adopted in some Universities is the "build, operate and transfer" (BOT) model which will ensure all admitted students are provided with reasonable accommodation. [21, 22] This will invariably improve the academic attainments of its students. Notwithstanding, it is imperative that students should pay stringent attention to the rules and regulations guiding the use of accommodation in the hostels.

\section{Conclusion}

Inadequate accommodation in university impacts negatively on the health and well being of students thereby culminating in their poor academic performance. The need to ensure safety in students' hostels will require continued advocacy to hostel managers, school authorities and other stakeholders. It is thereby advocated that universities need to engage in public private partnership to build more hostels within the University premises. This will ensure students are provided with reasonable accommodation thereby guaranteeing improved health and safety.

\section{References}

[1] Ojogwu C, Alutu A. Analysis of the Learning Environment of University Students on Nigeria: A Case Study of University of Benin. Journal of Social Sciences. 2009;19(1):69-73.

[2] Ali S, Haider Z, Munir F, Khan H, Ahmed A. Factors contributing to the students academic performance: A case study of Islamia University Sub-Campus. American Journal of Educational Research. 2013;1(8):283-9.

[3] Modebelu MN, Chinyere AP. Environmental hazards and hostel accommodation problems: Challenges for university education in Nigeria. US-China Education Review B, Education Theory, 4 (6), 407. 2014;413.

[4] Ekanem EE, Udida LA. Staff-personnel management towards technical and vocational education: Management implications for university graduate employability in Cross River State, Nigeria. European Journal of Training and Development Studies. 2014;2(1):22-30.

[5] Akuegwu BA, Nwi-ue FD. Appraisal of University Students' possession of Employment Skills for Global Workplace in SouthSouth, Nigeria. Journal of Educational Review. 2013;6(3).

[6] Francis D-AI. Solving the Problem of Poor Quality of University Graduates in Nigeria-A Proposed Holistic Approach. British Journal of Education. 2015;3(7):52-70.

[7] tokunefor T. Why Nigerian Universities Produce Poor Quality Graduates. Alpha Education Foundation Educational Monograph Series. 2011;3:1-22.

[8] Arkesteijn M, Valks B, Binnekamp R, Barendse P, De Jonge $\mathrm{H}$. Designing a preference-based accommodation strategy: A pilot study at Delft University of Technology. Journal of Corporate Real Estate. 2015;17(2):98-121.

[9] Kazeem K, Ige O. Redressing the growing concern of the education sector in Nigeria. Edo Journal of Counselling. 2010;3(1):40-9.

[10] 10. Yusuff OS. Students Access to Housing: A case of Lagos State University Students-Nigeria. Journal of Sustainable Development. 2011;4(2):107.

[11] Aluko OE. The Assessment of Housing Situation among Students in the University of Lagos. African Research Review. 2011;5(3).

[12] Wilkinson D. Poor housing and ill health: A summary of research evidence: Scottish Office; 1999.

[13] Anokye PA, Mohammed A. Students' Accommodation and Security Implications: A study of some selected hostels of the Kwame Nkrumah University of Science and Technology; Ghana. Imperial Journal of Interdisciplinary Research. 2016; 2 (8).

[14] Boro P, Soyam VC, Anand T, Kishore J. Physical Environment and Hygiene status at food service establishments in a tertiary care medical college campus in Delhi: A Cross-sectional study. Asian Journal of Medical Sciences (E-ISSN 2091-0576; P-ISSN 2467-9100). 2015;6(4):74-9.

[15] Uchenna EB, editor. Undergraduate's religious affiliation and interpersonal relationships in University of Nigeria Nsukka (Unn) and Nnamdi Azikiwe University (Nau) Awka. Refereed Proceedings of TASA 2016 Conference; 2016.

[16] Bronzaft AL. The effect of a noise abatement program on reading ability. Journal of environmental psychology. 1981;1(3):215-22.

[17] Marshy M. Social and Psychological Effects of Overcrowding in Palestinian Refugee Camps in the West Bank and Gaza. Literature Review and Preliminary Assessment of the Problem. International Development Research Centre. 1999;8. 
[18] Okpala PU, Iheanacho PN, Okoronkwo I, Stephens R. Students' Perception of Environmental Sanitation in Female Hostels-A Study of a Nigerian University. West African Journal of Nursing. 2014;25(1).

[19] Olusegun-Joseph T, Oboh M, Uduak M. A survey of malaria prevalence and antimalarial preventive measures amongst students of University of Lagos, Nigeria. African Journal of Clinical and Experimental Microbiology. 2016;17(4):267-73.

[20] Dunn JR. Housing and inequalities in health: a study of socioeconomic dimensions of housing and self reported health from a survey of Vancouver residents. Journal of epidemiology and community health. 2002;56(9):671-81.
[21] Yang J, Nisar T, Prabhakar GP. Critical success factors for build-operate-transfer (BOT) projects in China. Irish Journal of Management. 2016.

[22] $\mathrm{Hu} \mathrm{H}, \mathrm{Zhu}$ Y. Social Welfare-Based Concession Model for Build/Operate/Transfer Contracts. Journal of Construction Engineering and Management. 2014;141(1):04014064. 